\title{
ALQURAN TEACHING MODEL : THE EFFECT OF PROBLEM SOLVING ABILITY AND GENDER ON MATHEMATICS
}

\author{
Suherman \\ Fakutlas Tarbiyah dan Ilmu Keguruan, UIN Raden Intan, suferman@radenintan.ac.id \\ Ayu Sekarsari Suharno \\ Fakutlas Tarbiyah dan Imu Keguruan, UIN Raden Intan, ayusekarsari04@gmail.com \\ Istihana \\ Fakutlas Tarbiyahdan Ilmu Keguruan, UIN Raden Intan, istihana@radenintan.ac.id
}

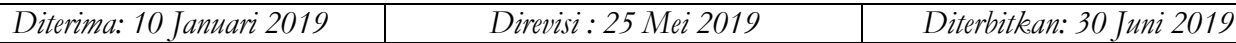

\begin{abstract}
Mathematical problem solving ability needs to be owned by students in learning. Students have low mathematical problem solving abilities caused by difficulties in solving mathematical problems that require logic. The research is aimed to determine the effect of the Alqurun Teaching Model on mathematical and gender problem solving abilities. This research is quantitative research. The population were 264 students eighth grade of SMPN 17 Bandar Lampung. The technique was random sampling technique. The data analysis used the normality test with Liliefors test and homogeneity test with Barlett test. The bypothesis testing was by using the two-way ANAVA test is not the same. The results showed that there was an influence of the Alqurun Teaching Model (ATM) toward the students' learning model on mathematical and gender problem solving abilities. The mathematical problem solving abilities of female students were better than male students in the Alqurun Teaching Model learning.
\end{abstract}

Keywords: Alqurun Teaching Model, Gender, Mathematical Problem Solving.

\begin{abstract}
Abstrak
Kemampuan pemecahan masalah matematis merupakan salah satu hal yang harus dimiliki oleh peserta didik dalam belajar matematika. Peserta didik memiliki kemampuan pemecahan masalah matematis yang rendah disebabkan oleh kesulitan dalam menyelesaikan masalah matematis yang membutuhkan logika. Tujuan penelitian ini adalah untuk mengetahui pengaruh Alqurun Teaching Model terhadap kemampuan pemecahan masalah matematis dan gender. Penelitian ini merupakan penelitian kuantitatif. Populasi dalam penelitian ini adalah 264 peserta didik kelas VIII SMP Negeri 17 Bandar Lampung. Teknik pengambilan sampel menggunakan teknik Sampel Random Sampling. Teknik analisis data menggunakan uji normalitas dengan uji Liliefors dan uji homogenitas dengan uji Barlett. Uji hipotesis menggunakan uji ANAVA dua jalan sel tak sama. Hasil penelitian menunjukkan bahwa terdapat pengaruh model pembelajaran Alqurun Teaching Model (ATM) terhadap kemampuan pemecahan masalah matematis dan gender. Kemampuan pemecahan masalah matematis peserta didik perempuan lebih baik daripada peserta didik laki-laki dalam pembelajaran Alqurun Teaching Model.
\end{abstract}

Kata Kunci: Alqurun Teaching Model, Gender, Pemecahan Masalah Matematis.

\section{Latar Belakang}

Perkembangan ilmu pengetahuan dan teknologi yang semakin pesat mengakibatkan suatu perubahan di berbagai bidang, khususnya bidang pendidikan. Pendidikan merupakan serangkaian kegiatan sistematis yang diarahkan 
terhadap perubahan tingkah laku peserta didik yang tercermin dalam keimanan dan ketaqwaan, pengetahuan, sikap dan tingkah laku dilingkungan keluarga, sekolah dan masyarakat.

Pendidikan adalah proses untuk memberikan manusia berbagai macam situasi yang bertujuan memberdayakan diri. Banyak hal yang menyangkut pendidikan, salah satunya aspek pendidikan. Aspek-aspek dalam pendidikan biasanya paling dipertimbangkan antara lain penyadaran, pencerahan, pemberdayaan, dan perubahan perilaku. Berbagai teori dan konsep pendidikan mendiskusikan apa dan bagaimana tindakan yang paling efektif mengubah manusia agar terbedayakan, tercerahkan, tersadarkan, dan menjadikan manusia sebagaimana mestinya manusia $^{1}$

Pendidikan adalah salah satu faktor penting dalam pembangunan nasional, yang berfungsi sebagai upaya untuk meningkatkan kualitas hidup manusia ${ }^{2}$. Pembelajaran dalam pendidikan diupayakan agar sumber daya manusia yang dalam hal ini adalah peserta didik, mampu berkembang dengan baik ${ }^{3}$ Proses pembelajaran merupakan suatu proses interaksi antara peserta didik dengan pendidik dan sumber belajar dalam suatu lingkungan tertentu. Proses pembelajaran yang dilakukan di dalam kelas merupakan aktivitas mentransformasikan pengetahuan, sikap, dan keterampilan. ${ }^{4}$ Dalam pembelajaran, guru

1 Imamuddin, M., \& Isnaniah. (2017). Kemampuan Spasial Mahasiswa Laki-laki dan Perempuan Dalam Menyelesaikan Masalah Geometri. Humanisma : Jurnal of Gender Studies, 1, 38-47.

2 Wulandari, P., Mujib, \& Ganda Putra, F. (2016). Pengaruh Model Pembelajaran Investigasi Kelompok berbantu Perangkat Lunak Maple terhadap Kemampuan Pemecahan Masalah Matematis. Al-jabar: Jurnal Pendidikan Matematika, 7(1), 101-107.

3 Rahma, S., Farida, \& Suherman. (2017). Analisis Berpikir Kritis Siswa dengan Pembelajaran Socrates Kontekstual di SMP Negeri 1 Padangratu Lampung Tengah. Prossiding Seminar Nasional Pendidikan IP A FITKUIN Syarif Hidayatullah Jakarta.

4 Yamin, M. (2007). Profesionalisasi Guru dan bertindak sebagai fasilitator yaitu guru berperan dalam memberikan pelayanan untuk memudahkan peserta didik dalam kegiatan proses pembelajaran. Pembelajaran tidak berpusat pada guru, peserta didik harus aktif sebagai pelaku utama ${ }^{5}$. Pembelajaran pembelajaran matematika merupakan serangkaian kegiatan peserta didik dalam pemahaman, pengetahuan, sikap, dan keterampilan tentang matematika yang dibimbing oleh guru untuk mencapai tujuan tertentu. Tujuan umum pembelajaran matematika pada jenjang pendidikan menengah adalah memberikan penekanan pada keterampilan dalam penerapan matematika, baik dalam kehidupan sehari-hari maupun dalam membantu mempelajari ilmu pengetahuan lainnya ${ }^{6}$. Sejalan dengan hal itu tentunya pendidikan tidak bisa dipisahkan dengan pembelajaran matematika karena pembelajaran yang kompleks dari semua tingkatan ${ }^{7}$.

Di dalam Alquran disebutkan kedudukan orang yang berilmu yaitu pada Surah Al-Mujadalah ayat 11 artinya:

Artinya: "Hai orang-orang yang beriman apabila dikatakan kepadamu: "Berlapang-lapanglah dalam majelis", Maka lapangkanlab niscaya Allah akan memberi kelapangan untukmu dan apabila dikatakan: "Berdirilah kamu", Maka berdirilah, niscaya Allah akan meninggikean orangorang yang beriman di antaramu dan orang-orang yang diberi ilmu pengetabuan beberapa derajat dan Allah Maha mengetahui apa yang kamu kerjakan.

Orang yang beriman dan memiliki ilmu pengetahuan akan diberi kepercayaan untuk

Implementasi KTSP. Jakarta: Gaung Persada Press.

${ }^{5}$ Sanjaya, W. (2006). Strategi Pembelajaran Berorientasi Standar Proses Pendidikan. Bandung: Kencana Media.

6 Suherman, E. (2003). Strategi Pembelajaran Matematika Kontemporer. Pascasarjana IKIP Bandung: Tidak diterbitkan.

7 Agustiana, E., Putra, F. G., \& Study, L. (2018). Pengaruh Auditory, Intellectually, Repetition ( AIR) dengan Pendekatan Lesson Study terhadap Kemampuan Pemecahan Masalah Matematis. Desimal: Jurnal Matematika, 1(1), 1-6. 
mengendalikan atau mengelolah apa saja yang terjadi dalam kehidupan ini. Ilmu didapatkan melalui pendidikan. ${ }^{8}$

Pandangan islam menuntut ilmu adalah suatu individu. Ilmu dapat diperoleh dimana saja salah satunya melalui lembaga pendidikan sekolah. Sekolah merupakan sarana dan prasarana untuk peserta didik meningkatkan diri.

Matematika merupakan dispilin ilmu yang mempunyai sifat khas kalau dibandingkan dengan disiplin ilmu yang lain. Karena kegiatan belajar mengajar matematika seyogyanya juga tidak disamakan begitu saja dengan ilmu yang lain (Herman Hudoyo, 1998). Dalam pembelajaran matematika metode mempunyai andil cukup besar dalam kegiatan belajar mengajar. Kemampuan yang diharapkan dapat dimiliki anak didik, akan ditentukan oleh kerelevensian penggunaan suatu metode yang sesuai dengan tujuan pembelajaran akan dapat dicapai penggunaan metode yang tepat, sesuai dengan standar keberhasilan yang terpatri di dalam suatu tujuan'.

Sekolah-sekolah yang berada ditingkat SD, SMP, maupun SMA mulai bersaing untuk menciptakan suatu sistem pendidikan yang dianggap mampu menjadikan peserta didik bersaing ditengah gencarnya industrialisasi dan mengembangkan prestasi peserta didik dengan baik, salah satunya adalah sistem Full Day School. Sistem Full Day School menerapkan pola waktu pembelajaran yang lebih lama dan tentunya dengan alasan dan tujuan yang matang. Menurut Elicker dan Marthur anak yang sekolah Full Day School memiliki kesiapan belajar yang lebih tinggi daripada anak-anak yang sekolah setengah hari, sehingga secara

8 Indah Muliati dan Muhamad Rezi, "Tujuan Pendidikan Dalam Lingkup Kajian Tafsir Tematik Pendidikan," Islam Transformatif: Journal of Islamic Studies 1, no. 2 (March 6, 2018): 177-90, https://doi.org/10.30983/IT.V1I2.475.

9 Djamrah, S. B., \& Zain, A. (2010). Strategi Belajar Mengajar. Jakarta: Rineka Cipta. tidak langsung hal ini akan berpengaruh pada prestasi anak.

Kegiatan pembelajaran hendaknya dilakukan dengan diawali penyajian suatu masalah untuk menghasilkan masalah. Kemampuan pemecahan masalah dalam pembelajaran matematika merupakan hal yang sangat penting dikembangkan ${ }^{10}$. Kemampuan pemecahan masalah matematis yang sesuai dengan permasalahan dapat dijadikan gagasan atau ide-ide matematika lebih kongkrit dan membantu peserta didik untuk memecahkan suatu masalah yang kompleks menjadi lebih sederhana. Memecahkan masalah maka peserta didik diberi banyak kesempatan untuk menghubungkan ide matematika dan untuk mengembangkan pemahaman konseptual. Tetapi pada kenyataannya, lagi-lagi kemampuan pemecahan masalah dalam matematika tetap menjadi permasalahan yang paling mendasar. Pentingnya kepemilikan kemampuan pemecahan masalah tersebut tercermin dalam kutipan Branca yang menyatakan bahwa pemecahan masalah matematis merupakan salah satu tujuan penting dalam pembelajaran matematika bahkan proses pemecahan masalah matematis merupakan jantungnya matematika ${ }^{11}$.

Alasan pentingnya memberikan soalsoal kemampuan pemecahan masalah matematis kepada peserta didik yaitu dapat menimbulkan keingintahuan, memotivasi, dan membantu berpikir kreatif peserta didik. Memiliki pengetahuan dan keterampilan berhitung, dan lain-lain, diisyaratkan adanya kemampuan untuk keterampilan berhitung, dan lain-lain, diisyaratkan adanya kemampuan untuk terampilan membaca dan membuat pernyataan yang benar, serta dapat menambah pengetahuan baru, dapat menimbulkan aplikasi

10 Rosalina, T. (2008). Pengaruh Manajemen Pembelajaran Full Day School Terhadap Motivasi Belajar. Manajemen Pendidikan, 23(5), 434-438.

11 Soemarno U dan Hendriana H. (2014). Penilaian Pembelajaran Matematika. Bandung: PT Refika Aditama. 
ilmu pengetahuan yang sudah diperoleh, mengajak peserta didik memiliki prosedur pemecahan masalah, mampu membuat analisis dan sintesis, dan menuntut untuk membuat evaluasi terhadap hasil pemecahnnya, dan merupakan kegiatan penting bagi peserta didik yang melibatkan bukan satu bidang studi tetapi bila diperlukan mungkin bidang atau pelajaran lain, sehingga merangsang peserta didik menggunakan segala kemampuannya dalam menyelesaikan permasalahan dalam menghadapi kehidupannya kini maupun kelak di kemudian hari ${ }^{12}$. Dengan demikian, jika peserta didik belum menguasai konsep yang mendasar maka akan sulit menguasai konsep yang lebih lanjut ${ }^{13}$. Menurut Tya Anggaeni faktor yang mempengaruhi kecemasan peserta didik dalam menghadapi mata pelajaran matematika adalah jenis kelamin, usia dan kelas $^{14}$.

Peraturan pemerintah Nomor 19 Tahun 2005 tentang Standar Nasional Pendidikan dinyatakan bahwa proses pembelajaran pada satuan pendidikan haruslah interaktif, menyenangkan, dan dapt memotivasi peserta didik untuk berpartisipasi aktif dalam proses pembelajaran. Dengan demikian, selama proses pembelajaran berlangsung peserta didiklah yang dituntut harus berperan aktif. Guru hanya sebagai fasilitator dan motivator yang bertugas memfasilitasi dan mengarahkan pola berpikir peserta didik.

Akan tetapi, pada kenyataannya sebagian besar proses pembelajaran khususnya pembelajaran matematika masih berpusat pada guru. Pembelajaran yang demikian cenderung

${ }^{12}$ Ruseffendi, E. T. (1991). Penilaian Pendidikan dan Hasil Belajar Siswa khususnya dalam Pengajaran Matematika.

${ }^{13}$ Fedi, S., Sariyasa, \& Suparta, I. N. (2014). Tingkat Kecemasan dan Apresiasi Matematika Ditinjau dari Gender pada Siswa kelas VIII SMP Negeri Sekecamatan Poco Ranaka Barat, Kabupaten Manggarai Timur Tahun Ajaran 2013/2014. Jurnal Stkip Santu Paulus.

14 Amir MZ, Z. (2013). Perspektif Gender dalam Pembelajaran Matematika. Marwah, 12(1), 14-31. membuat peserta didik kurang aktif dan peserta didik hanya diberi kesempatan untuk mendengarkan, mencatat, dan mengerjakan soal sesuai dengan apa yang guru jelaskan. Padahal seharusnya, selama proses pembelajaran peserta didik diberikan kesempatan seluas-luasnya untuk dapat mengembangkan kemampuan berpikirnya.

Disisi lain lain, kemampuan pemecahan masalah matematis penting dikembangkan dan dimiliki peserta didik. Hal ini dapat dilihat dari pra survei yang dilakukan peneliti di SMP Negeri 17 Bandar Lampung pada tanggal 19 Juli Tahun Ajaran 2018/2019 menunjukkan bahwa sebagian besar nilai matematika peserta didik masih berada dibawah standar Kriteria Ketuntasan Minimum (KKM), KKM yang ditetapkan oleh sekolah tersebut untuk pelajaran matematika adalah 71,00. Berikut tabel hasil tes kemampuan pemecahan masalah matematis peserta didik SMP Negeri 17 Bandar Lampung Tahun Ajaran 2018/2019.

Tabel 1. Nilai Tes Kemampuan Pemecahan Masalah Matematis Peserta Didik Kelas VIII SMP Negeri 17 Bandar Lampung

\begin{tabular}{|l|c|l|l|}
\hline \multirow{2}{*}{ Kelas } & \multicolumn{2}{|c|}{ Nilai Peserta } & \multirow{2}{*}{ Jumlah } \\
\cline { 2 - 4 } & $\boldsymbol{x}<\mathbf{7 3}$ & $\boldsymbol{x} \geq \mathbf{7 3}$ & \\
\hline \multirow{2}{*}{ I 9} & 19 & 11 & 30 \\
\hline Jumlah & 19 & 11 & 30 \\
\hline Persentase & $63,33 \%$ & $36,67 \%$ & $100 \%$ \\
\hline
\end{tabular}

Sumber: Nilai Tes Kemampuan Pemecahan Masalab Matematis Kelas VIII 9 Tabun Pelajaran 2018/2019

Berdasarkan data kemampuan pemecahan masalah matematis tersebut menunjukkan bahwa dari 30 peserta didik, 19 peserta didik diantaranya mendapatkan nilai dibawah KKM (Kriteria Ketuntasan Minimal) dengan persentase 63,33\%. Dalam hal ini KKM di SMP Negeri 17 Bandar Lampung adalah 71,00 , sedangkan 11 peserta didik mendapatkan nilai di atas KKM dengan 
persentase 36,67\%. Hal ini berarti pencapaian peserta didik kurang memuaskan disebabkan peserta didik menganggap bahwa pelajaran matematika merupakan pelajaran yang sulit dan menakutkan, sehingga peserta didik tidak bisa mendapatkan nilai yang baik.

Berdasarkan hasil wawancara pra survey yang dilakukan peneliti kepada Ibu Asmara Dewi, S.Pd. selaku guru matematika kelas VIII SMP Negeri 17 Bandar Lampung mengungkapkan bahwa beliau masih sering menggunakan model pembelajaran konvensional untuk menyampaikan materi yang telah disiapkan lalu memberikan latihanlatihan soal yang bersifat mandiri, terkadang diberikan tugas secara kelompok. Beliau juga mengatakan bahwa kemampuan pemecahan masalah matematis peserta didik perempuan dan peserta didik laki-laki cenderung rendah.

Gender tentu menyebabkan perbedaan fisiologi dan memengaruhi perbedaan psikologis dalam belajar. Sehingga peserta didik laki-laki dan perempuan tentu memiliki banyak perbedaan dalam mempelajari matematika. Aspek gender perlu dalam pembelajaran matematika dengan kata lain perubahan proses belajar matematika yang menyenangkan memperhatikan aspek perbedaan jenis kelamin sehingga peserta didik laki-laki dan perempuan tidak lagi takut atau cemas dalam pelajaran matematika.

Penjabaran di atas, maka guru harus mampu memilih dan menerapkan model pembelajaran yang sesuai dengan tujuan pembelajaran yang akan dicapai. Memilih suatu model pembelajaran guru harus memiliki pertimbangan-pertimbangan materi pelajaran, tingkat perkembangan kognitif peserta didik sehingga tujuan pembelajaran yang telah diterapkan dapat tercapai, maka perlu diterapkan suatu model pembelajaran yang dapat melibatkan secara aktif peserta didik dalam kegiatan belajar mengajar dan tidak hanya mentransfer pengetahuan kepada peserta didik tetapi mampu merangsang daya berpikir peserta didik untuk membentuk pengetahuan mereka sendiri dalam memecahkan masalahmasalah matematika yang dihadapi.

Model pembelajaran yang akan diterapkan, diharapkan peserta didik mampu membangun, mengembangkan bahkan meningkatkan kemampuan pemecahan masalah matematis peserta didik baik laki-laki maupun perempuan.

Salah satu alternatif model pembelajaran yang diharapkan dapat memfasilitasi peserta didik untuk meningkatkan kemampuan pemecahan masalah matematis yaitu model pembelajaran Alqurun Teaching Model (ATM).

Model pembelajaran Alqurun Teaching Model adalah model pembelajaran yang memiliki urutan dengan memadukan antara memodifikasi Taksonomi Bloom dan kompetensi kurikulum 2013 (Amalia, 2017). Model pembelajaran Alqurun Teacbing Model memiliki tahapan-tahapan yaitu ecknowledge (pengakuan), literature (penelusuran pustaka), quest (menyelidiki/menganalisis), unite (menyatukan/mensistesis), refine (menyaring), use (penerapan), dan name (menamakan).

Berikut tahap-tahap model pembelajaran ATM (Oktiana, 2017):

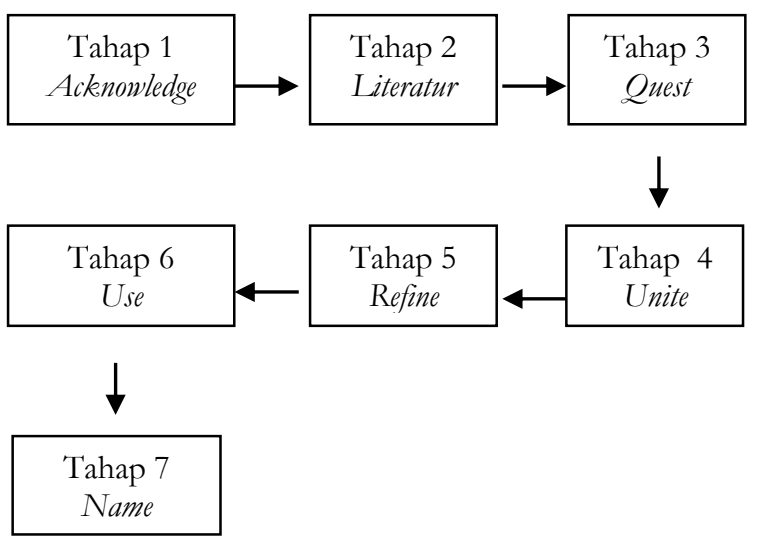

Tahap pertama yaitu eknoowladge, ini merupakan tahap pada kegiatan pendahuluan. Peserta didik akan diberi pemanasan sebelum memasuki kegiatan inti yaitu dengan diberikan apersepsi dan penghargaan (pujian) atas pengetahuan yang peserta didik miliki saat itu. 
Selanjutnya literature, tahap ini merupakan tahap pertama dalam kegiatan inti. Peserta didik akan melakukan penelusuran pustakamengenai materi yang akan dipelajari melalui literatur yang tersedia secara individu. Tahap ketiga yaitu quest, peserta didik akan melakukan pengamatan terhadap beberapa kegiatan dan permasalahan dari materi yang dipelajari. Pada saat peserta didik melakukan aktivitas ini, maka guru berperan memberikan bimbingan, bantuan, dan pendampingan. Tahap keempat (unite), setelah peserta didik melakukan pengamatan maka peserta didik akan menyelesaikan beberapa permasalahan dari materi yang dipelajari. Peserta didik melakukan pengamatan dan penyelesaian masalah sesuai dengan literatur yang telah ditelusuri sebelumnya.

Kemudian tahap kelima yaitu refine, peserta didik akan membuat kesimpulan dari hasil pengamatan dan penyelesaian mengenai kegiatan serta permasalahan yang sebelumnya telah diselesaikan. Pada tahap ini peserta didik dan guru akan berdiskusi untuk menyamakan persepsi serta menghasilkan suatu konsep yang matang. Selanjutnya pada tahap use, peserta didik akan mengaplikasikan pengetahuan yang telah dimilikinya dengan cara mengerjakan soal-soal yang diberikan oleh guru. Di sini peserta didik dilatih untuk dapat menggunakan, memanfaatkan, dan memilih prosedur atau operasi. Tahap terakhir yaitu name, setelah peserta didik mengerjakan soal latihan yang diberikan, kemudian peserta didik menamakan cara tersebut sesuai keinginannya. Model ini mengajak peserta didik untuk lebih aktif dalam pembelajaran karena mengerjakan soal dengan caranya sendiri kemudian memberi nama dari cara baru penyelesaian masalah/soal sehingga dapat meningkatkan pemahaman peserta didik terhadap keaktifan belajar dan kemampuan pemecahan masalah matematika.

Alqurun Teacbing Model memiliki keunggulan diantaranya bahwa peserta didik dapat terbiasa unutuk menyelesaikan atau memecahkan masalah soal-soal, peserta didik dapat mengekspresikan idenya melalui pemberian nama dari cara baru penyelesaian masalah atau soal, peserta didik dengan kemampuan matematika rendah dapat merespon permasalahan dengan cara mereka sendiri.

Penilitian Alqurun Teaching Model telah banyak dilakukan oleh peneliti lain, diantaranya bahwa LKPD berbasis Alqurun Teaching Model efektif untuk meningkatkan kemampuan komunikasi matematis peserta didik (Astri Setyawati, 2017). Senada dengan itu, bahwa kemampuan pemahaman konsep matematis peserta didik menggunakan LKPD berbasis Alqurun Teaching Model lebih tinggi daripada yang tidak menggunakan LKPD berbasis Alqurun Teaching Model ${ }^{15}$. Dipihak lain, pengembangan bahan ajar berbasis Alqurun Teaching Model Pada Teorema Phytagoras efektif digunakan dengan hasil ketuntasan posttest peserta didik menunjukkan $76 \%$ berhasil mencapai $\mathrm{KKM}^{16}$.

Berdasarkan penelitian di atas, penelitian ini memiliki kebaruan, diantaranya bahwa Alqurun Teaching Model dipadukan dengan kemampuan pemecahan masalah dan gender. Dengan hal itu, bahwa kebaruan ini akan memberikan dampak positif terhadap tmuan yang didapat.

Upaya yang dilakukan penulis untuk membedakan penelitian ini dengan penelitian terdahulu adalah dengan mengkombinasikan model pembelajaran Alqurun Teaching Model terhadap kemampuan pemecahan masalah matematis, yang diharapkan dapat membuat peserta didik lebih aktif dalam proses pembelajaran. Penelitian tentang pemecahan masalah matematis bahwa penerapan

15 Puspitasari, Y. (2017). Pengembangan LKPD Berbasis Alqurun Teacbing Model untuk meningkatkan Pemahaman Konsep Matematika. Skripsi Universitas Lampung.

16 Yenda Bella Putri. (2017). Pengembangan Bahan Ajar Berbasis Alqurun Teaching Model Pada Teorema Phytagoras. Skripsi Universitas Lampung. 
pendekatan kontekstual berbantu Hands On Activity (HoA) memiliki kemampuan pemecahan masalah matematis lebih baik dibandingkan peserta didik yang diberikan model pembelajaran konvensional ${ }^{17}$. Pada penelitian terdahulu tentang kemampuan pemecahan masalah matematis, belum ada penelitian yang menganalis kemampuan pemecahan masalah matematis yang ditinjau dari perbedaan gender.

Perbedaan gender, tidak hanya melihat dari tingkah laku peserta didik laki-laki atau perempuan tetapi juga tetapi melihat juga dari pola pikir laki-laki dan perempuan dalam mengerjakan soal. Menurut Pudjijogyanti pembentukan konsep diri antara laki-laki dan perempuan mengalami perbedaan ${ }^{18}$. Penerapan perbedaan gender juga pernah dilakukan oleh Siska Chindy Dilla dalam penelitiannya menunjukkan bahwa kemampuan berpikir kreatif dipengaruhi oleh gender dan resiensi peserta didik. Gender merupakan suatu istilah yang digunakan untuk menggambarkan perbedaan antara laki-laki dan perempuan secar sosial. Gender merupakan jenis kelamin bawaan lahir yang dipengaruhi oleh faktor sosial dan budaya serta karakteristik yang membe-dakan antara individu-individu ${ }^{19}$. Perbedaan ini sangat penting, karena selama ini sering dicampur-adukkan antara ciri-ciri manusia yang bersifat kodrati dan tidak berubah dengan ciri-ciri manusia yang bersifat non kodrati (gender) yang sebenarnya bisa berubah dan diubah ${ }^{20}$.

17 Yenda Bella Putri. (2017). Pengembangan Bahan Ajar Berbasis Alqurun Teaching Model Pada Teorema Phytagoras. Skripsi Universitas Lampung.

18 Syawaluddin. (2017). Konsep Diri Anak Ditinjau Dari Jenis Kelamin Di Panti Asuhan Kota Padang. Humanisma : Jurnal of Gender Studies, 1(1), 75-86.

19 Subarinah, S. (2013). Profil Berpikir Kreatif Siswa dalam Memecahkan Masalah Tipe Investigasi Matematik Ditinjau dari Perbedaan Gender FMIPA UNY. Seminar Nasional Matematika dan Pendidikan Matematika.

${ }^{20}$ Hasnah, N. (2017). Bias Gender Dalam Buku Ajar Al-Arabiyah Linnaasyiin. Humanisma: Jurnal of Gender Studies, 1, 61-74.
Berdasarkan sisi ini gender dipahami sebagai sebuah konsep yang dijadikan parameter dalam mengidentifikasi peran lakilaki dan perempuan yang didasarkan pada pengaruh sosial budaya masyarakat (social cotruction) dengan tidak melihat jenis biologis secara equality dan tidak menjadikannya sebagai alat pendiskriminasian salah satu pihak karena pertimbangan yang sifatnya biologis.

Berdasarkan beberapa definisi di atas dapat dipahami bahwa gender adalah suatu sifat yang dijadikan dasar untuk mengidentifikasi antara laki-laki dan perempuan dilihat dari segi kondisi sosial dan budaya. Gender dalam hal ini adalah suatu bentuk rekayasa masyarakat, bukannya sesuatu yang bersifat kodrati.

Berangkat dari beberapa fenomena yang terjadi di lapangan, maka dalam hal ini peneliti tertarik melakukan penelitian mengenai pengaruh Alqurun Teaching Model (ATM) terhadap kemampuan pemecahan masalah matematis ditinjau dari perbedaan gender peserta didik (Full Day School).

\section{Metodologi}

Penelitian ini yang digunakan adalah penelitian kuantitatif dengan menggunakan metode Quasi Eksperimental Design (desain eksperimen semu). Kelas dibagi menjadi 2 kelas, eksperimen yang pembelajarannya menggunakan model Alqurun Teaching Model (ATM) dan kelas yang pembelajarannya menggunakan model pembelajaran konvensional. Rancangan desain posttest-only control desain adalah sebagai berikut:

Tabel 2. Rancangan Penelitian

\begin{tabular}{|r|l|l|}
\hline \multirow{2}{*}{$\begin{array}{r}\text { Kelamin }\left(B_{j}\right) \\
\text { Model }\left(A_{i}\right)\end{array}$} & $\begin{array}{l}\text { Jenis } \\
\left(B_{1}\right)\end{array}$ & $\begin{array}{l}\text { Gerempuan } \\
\left(B_{2}\right)\end{array}$ \\
\cline { 2 - 3 }
\end{tabular}




\begin{tabular}{|l|l|l|}
\hline $\begin{array}{l}\text { lqurun Teaching model } \\
(\mathrm{ATM})\left(A_{1}\right)\end{array}$ & $A_{1} B_{1}$ & $A_{1} B_{2}$ \\
\hline Konvensional $\left(A_{2}\right)$ & $A_{2} B_{1}$ & $A_{2} B_{2}$ \\
\hline
\end{tabular}

Keterangan:

$A_{i} \quad=$ Model Pembelajaran

$B_{j} \quad=$ Gender

$A_{1} \quad=$ Model Pembelajaran Alqurun

Teaching Model (ATM)

$A_{2}=$ Model Pembelajaran

Konvensional

$B_{1}=$ Gender (Laki-laki)

$B_{2} \quad=$ Gender (Perempuan)

$A_{1} B_{1}=$ Hasil tes kemampuan pemecahan masalah matematis melalui model pembelajaran ATM dan gender laki-laki

$A_{1} B_{2}=$ Hasil tes kemampuan pemecahan masalah matematis melalui model pembelajaran ATM dan gender perempuan

$A_{2} B_{1}=$ Hasil tes kemampuan pemecahan masalah matematis melalui model pembelajaran konvensional dan gender laki-laki

$A_{2} B_{2}=$ Hasil tes kemampuan pemecahan masalah matematis melalui model pembelajaran konvensional dan gender perempuan

Populasi dalam penelitian ini adalah seluruh kelas VIII SMP Negeri 17 Bandar Lampung yang terdiri dari sembilan kelas yaitu VIII 1, VIII 2, VIII 3, VIII 4, VIII 5, VIII 6, VIII 7, VIII 8, dan VIII 9. Pengambilan sampel dilakukan dengan menggunakan teknik Sample Random Sampling yaitu teknik acak kelas tanpa memperhatikan strata yang ada pada populasi. Diperoleh dua sampel yaitu VIII 6 sebagai kelas eksperimen dengan menggunakan model pembelajaran Alqurun Teaching Model dan VIII 9 sebagai kelas kontrol dengan menggunakan model pembelajaran konvensional.

Data dalam penelitian ini adalah data kuantitatif yang diperoleh dari hasil tes uraian yang diberikan setelah selesai pembelajaran. Soal tes uraian tersebut haruslah layak untuk dijadikan sebagai alat tes untuk dapat mengukur kemampuan pemecahan masalah matematis. Tes yang dilakukan dalam penelitian ini dihitung menggunakan teknik penskoran yang sesuai yang indikator kemampuan pemecahan masalah matematis. Soal tersebut sebelumnya telah melalui tes validitas, setelah dinyakan valid lalu soal tersebut diuji cobakan diluar sampel penelitian. Setelah melalui beberapa tahapan barulah tes tersebut layak digunakan untuk mengumpulkan data hasil uji coba kemampuan pemecahan masalah matematis. Terdapat empat indikator kemampuan pemecahan masalah matematis yang digunakan dalam penelitian ini. Berikut indikator kemampuan pemecahan masalah matematis:

1. Mengidentifikasi masalah

2. Merencanakan pemecahan masalah

3. Menyelesaikan masalah

4. Mengevaluasi kembali pemecahan masalah

Selanjutnya peneliti menganalisis data yang telah diperoleh, peneliti melakukan uji prasyarat analisis yaitu uji normalitas dengan metode liliefors dan uji homogenistas dengan menggunakan uji barlett. Kemudian akan dilakukan uji hipotesis data dalam penelitian ini menggunakan uji Anava dua jalan sel tak sama (Novalia \& Syazali, 2014). Uji ini digunakan untuk melihat efek variabel bebas terhadap variabel terikat dengan membandingkan rataan beberapa kelompok.

\section{Deskripsi Data}

Data yang diperoleh disusun dalam tabel yang menggambarkan banyaknya responden dalam kelas eksperimen dan kontrol. Berikut data yang diperoleh:

Tabel 3. Perbedaan Gender

\begin{tabular}{|l|l|r|}
\hline \multicolumn{1}{|c|}{ Jenis } & \multicolumn{2}{|c|}{ Gender } \\
\cline { 2 - 3 } Melamin & $\begin{array}{l}\text { Laki- } \\
\text { laki }\end{array}$ & Perempuan \\
\hline Alqurun Teaching model (ATM) & 10 & 20 \\
\hline Konvensional & 15 & 15 \\
\hline
\end{tabular}


Berdasarkan tabel 1 di atas, dapat disimpulkan bahwa perbedaan gender menggunakan model pembelajaran Alqurun Teaching Model terdapat 10 peserta didik laki-laki dan pada model pembelajaran konvensional terdapat 15 peserta didik laki-laki. Sedangkan terdapat 20 peserta didik perempuan pada model pembelajaran Alqurun Teaching Model dan 15 peserta didik perempuan pada kontrol.

\section{Hasil dan Pembahasan}

Penelitian ini dilaksanakan di SMP Negeri 17 Bandar Lampung yang dilaksanakan mulai pada bulan Maret 2019. Pembelajaran yang dilaksanakan dalam penelitian ini yakni pembelajaran melalui model pembelajaran Alqurun Teaching Model.

Pembelajaran dengan menggunkan model pembelajaran Alqurun Teaching Model dapat mendorong peserta didik berperan secara aktif untuk menemukan hubungan materi yang dipelajari dengan kehidupan nyata sehingga pembelajaran menjadi lebih bermakna dan nyata.

Penelitian ini mempunyai dua variabel yang menjadi objek penelitian yaitu variabel bebas (Alqurun Teaching Model dan perbedaan gender) dan variabel terikat (kemampuan pemecahan masalah matematis). Materi yang diajarkan pada penelitian ini adalah materi bangun ruang sisi datar, yaitu kubus dan balok. Penelitian ini dilakukan tiga kali pertemuan dengan menerapkan model pembelajaran Alqurun Teacbing Model dan satu kali tes akhir (posttest) kemampuan pemecahan masalah matematis. Sebelum soal tes kemampuan pemecahan masalah matematis digunakan, terlebih dahulu divalidasi, kemudian diuji cobakan pada perserta didik kelas IX SMP Negeri 17 Bandar Lampung. Tujuan uji coba ini adalah untuk mengetahui validitas butir soal dan tingkat reabilitas soal tersebut.

Dari hasil uji coba, diketahui bahwa instrumen tes dengan koefisien reabilitas adalah 0,70. Hal ini menunjukkan bahwa instrumen tes memiliki kriteria tinggi. Daya pembeda butir soal yang digunakan memiliki kriteria baik dan sangat baik serta tingkat kesukaran memiliki kriteria mudah, sedang, dan sukar. Dengan demikian, soal tes kemampuan pemecahan masalah matematis sudah layak digunakan untuk mengumpulkan data. Hasil uji validitas, uji reliabilitas, uji tingkat kesukaran, dan uji daya pembeda, maka dapat dibuat tabel kesimpulan sebagai berikut:

Tabel 4. Kesimpulan Uji Coba Soal Kemampuan Pemecahan Masalah

\begin{tabular}{|l|l|l|l|}
\hline Validitas & \multirow{2}{*}{ Reliabilitas } & $\begin{array}{l}\text { Tingkat } \\
\text { Kesukaran }\end{array}$ & $\begin{array}{l}\text { Daya } \\
\text { Beda }\end{array}$ \\
\hline Valid & & Mudah & Sangat Baik \\
\hline Valid & & Sukar & Sangat Baik \\
\hline Valid & Sedang & Sangat Baik \\
\hline Valid & Reliabel & Sukar & Sangat Baik \\
& & Sukar & Sangat Baik \\
& Valid & Sudang & Sangat Baik \\
\hline Valid & Mudah & Sangat Baik \\
\hline Tidak Valid & & Sukar & Sangat Baik \\
\hline Tidak Valid & &
\end{tabular}

Pada pertemuan pertama, materi pembelajan adalah sifat-sifat kubus dan balok. Kendala yang dihadapi peserta didik masih terbiasa dengan model pembelajaran konvensional. Terlihat pada kegiatan menyelidiki (Quest) dan menggabungkan (Unite) dan menyaring (Refine), peserta didik lebih memilih untuk bertanya langsung penyelesaian masalahnya kepada guru dari pada memahami, mecari dan mendiskusikan terlebih dahulu kepada kelompoknya dari sumber belajar dan (Literature) yang mereka miliki. Padahal seharusnya guru hanya membantu peserta didik untuk membentuk pengetahuannya sendiri, bukan mentransfer pengetahuan yang dimiliki guru. Menurut pandangan konstruktivistik, peserta didik harus harus aktif melakukan kegiatan, aktif berpikir, menyusun konsep dan memberi makna tentang hal-hal yang sedang dipelajari, sementara guru dalam pembelajaran konstruktivistik berperan membantu agar proses pengkonstruksian pengetahuan oleh peserta didik berjalan lancar(Siregar,2010). 
Solusi agar pada pertemuan kedua tidak ada kendala yang sama sebelumnya sebelum mengakhiri pertemuan pertama peneliti menjelaskan lebih rinci bahwa pembelajaran yang peneliti berikan peserta didik diminta untuk berperan aktif dalam proses pembelajaran.

Selanjutnya pada pertemuan kedua, dengan materi luas permukaan kubus dan balok. Kendala pada pertemuan kedua hanya terletak pada waktu dan karena setiap kelompok dalam presentasi menjelaskan secara rinci dan terlalu banyak pertanyaan dari kelompok lain sehingga tidak semua kelompok maju ke depan untuk mempresentasikan hasil kerja kelompoknya dan pemberian nama dari penyelesaian masalah/soal yang mereka kerjakan. Solusi yang peneliti gunakan untuk pertemuan selanjutnya, peneliti membatasi atau memberikan waktu yang sama pada setiap kelompok dalam presentasi dan hanya tiga pertanyaan yang diajukan dari kelompok lain.

Pada pertemuan ketiga dengan materi volume kubus dan balok. Pertemuan keiga ini, peserta didik sudah mulai membiasakan untuk kondusif dan berusaha semua anggota terlibat aktif dalam penyelesaian LKPD dan kelompoknya. Peserta didik mengerjakan soal pada lembar LKPD kemudian mereka diminta untuk memberi nama dari penyelesaian soal yang peserta didik kerjakan. Kemudian peserta didik mempresentasikan jawaban soal dari pemberian nama yang mereka selesaikan secara berkelompok.

Secara keseluruhan pembelajaran dengan model pembelajaran Alqurun Tecahing Model berjalan dengan baik. Selama proses belajar terlihat adanya perubahan yang diperoleh peserta didik yakni meningkatnya kemampuan pemecahan masalah matematis peserta didik.

Berdasarkan hasil penelitian yang dilakukan pada bulan Maret 2019 didapatkan data nilai rata-rata kemampuan pemecahan masalah matematis peserta didik kelas Alqurum
Teacbing Model (ATM) adalah 75,53 dan ratarata kelas kelas konvensional (kontrol) sebesar 68,97. Berikut diagram tes kemampuan pemecahan masalah matematis peserta didik:

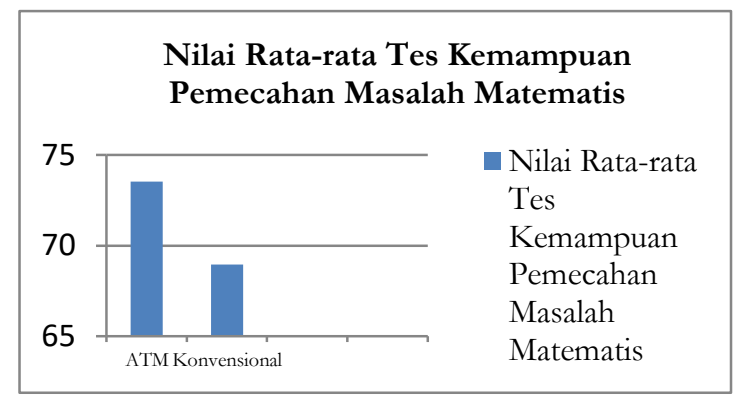

Gambar 1. Diagram Batang Rata-Rata Tes Kemampuan Pemecahan Masalah Matematis

Salah satu faktor yang penyebab skor rata-rata tes kemampuan pemecahan masalah matematis peserta didik dari kelas eksperimen dan kontrol tersebut berbeda-beda adalah proses pembelajaranmenggunakan model pembelajaran Alqurun Teaching Model menjadikan peserta didik belajar dengan optimal sehingga materi dapat diingat peserta didik lebih tinggi dan meningkatkan kemampuan peserta didik dalam memecahkan masalah matematis. Sedangkan proses pembelajaran dengan menggunakan model pembelajaran konvensional menekankan kepada situasi peneliti/pendidik mengajar bukan situasi peserta didik belajar. Kondisi ini menyebabkan peserta didik kurang mampu untuk mengingat materi serta kurang mampu menyelesaikan soal-soal matematika.

Sebelum melakukan uji hipotesis, terlebih dahulu dilakukan uji prasyarat hipotesis. Untuk mengetahui makakah yang memiliki pengaruh kemampuan pemecahan masalah matematis yang lebih baik Uji prasyarat tersebut meliputi uji normalitas dan uji homogenitas varians. Uji normalitas dilakukan pada data kemampuan pemecahan masalah matematis pada pelajaran matematika kelompok eksperimen dan kelompok kontrol dengan menggunakan uji lilifors. Hasil 
perhitungan dengan menggunakan analisis uji lilifors adalah sebagai berikut:

Tabel 5. Uji Normalitas

\begin{tabular}{|l|l|l|l|}
\hline Kelompok & $\boldsymbol{L}_{\text {hitung }}$ & $\boldsymbol{L}_{\text {tabel }}$ & Keputusan Uji \\
\hline $\begin{array}{l}\text { Eksperimen } \\
\left(A_{1}\right)\end{array}$ & 0,144 & 0,159 & $\begin{array}{l}\text { Berdistribus } \\
\text { Normal }\end{array}$ \\
\hline Kontrol $\left(A_{2}\right)$ & 0,154 & 0,159 & $\begin{array}{l}\text { Berdistribusi } \\
\text { Normal }\end{array}$ \\
\hline
\end{tabular}

Tabel menunjukkan bahwa $L_{\text {hitung }}$ pada kelas eksperimen kurang dari $L_{\text {tabel }}$ yaitu sebesar $0,144<0,159$ dan $L_{\text {hitung }}$ pada kelas kontrol kurang dari $L_{\text {tabel }}$ yaitu 0,154< 0,159 sehingga dapat disimpulkan bahwa data populasi kedua kelas tersebut berdistribusi normal.

Setelah melalui uji normalitas dan dinyatakan data berdistribusi normal maka dilakukan uji homogenitas. Uji homogenitas dilakukan untuk mengetahui apakah kedua sampel memiliki karakter yang sama atau tidak. Uji homogenitas varians untuk kedua kelompok menggunakan uji Barlett. Dari hasil perhitungan diperoleh bahwa $F_{\text {hitung }}=0,507$ sedangkan $F_{\text {tabel }}$ pada taraf signifikasi 5\% sebesar 3,481 yang berarti $F_{\text {hitung }}<F_{\text {tabel }}$ maka $H_{0}$ diterima. Dapat disimpulkan bahwa kedua kelompok penelitian memiliki varians yang homogen.

Berdasarkan hasil uji prasyarat yang telah dilakukan, dapat diketahui bahwa data kedua kelompok berdistribusi normal dan memiliki varians yang homogen. Dengan demikian uji hipotesis dengan uji Anava dapat dilakukan. Uji hipotesis yang digunakan dalam penelitian ini adalah uji Anava dua jalan sel tak sama, dengan kriteria pengujian adalah $H_{0}$ ditolak jika $F_{\text {hitung }}>F_{\text {tabel }}$.

Berdasarkan perhitungan analisis data dapat disimpulkan bahwa:

1) $F_{a}=19,071$ dan taraf signifikansi $5 \%$ diperoleh $\mathrm{F}_{(0,05 ; 1 ; 56)}=4,013$ sehingga $\mathrm{F}_{\mathrm{a}}>F_{(0,05 ; 1 ; 56)}$ yang menunjukkan bahwa $\mathrm{H}_{0 \mathrm{~A}}$ ditolak berarti ada pengaruh antara model pembelajaran Alqurun Teaching Model dengan peserta didik yang diberi pembelajaran konvensional terhadap kemampuan pemecahan masalah matematis peserta didik.

2) $F_{b}=11,198$ dan taraf signifikansi $5 \%$ diperoleh $\quad F_{(0,05 ; 1 ; 56)}=4,013$ sehingga $\quad \mathrm{F}_{\mathrm{b}}<\mathrm{F}_{(0,05 ; 1 ; 56)} \quad$ yang menunjukkan bahwa $\mathrm{H}_{0 \mathrm{~B}}$ ditolak berarti ada pengaruh antara perbedaan gender peserta didik terhadap kemampuan pemecahan masalah matematis/berhitung matematika peserta didik.

3) $\mathrm{F}_{\mathrm{ab}}=56$ dan taraf signifikansi 5\% diperoleh $\mathrm{F}_{(0,05 ; 1 ; 56)}=4,013$ sehingga $\mathrm{F}_{\mathrm{ab}}<\mathrm{F}_{(0,05 ; 1 ; 56)}$ yang menunjukkan bahwa $\mathrm{H}_{0 \mathrm{AB}}$ ditolak berarti terdapat interaksi antara model pembelajaran dan perbedaan gender peserta didik terhadap kemampuan pemecahan masalah matematis peserta didik.

Berdasarkan perhitungan anava dapat disimpulkan bahwa terdapat pengaruh penerapan model pembelajaran ATM terhadap kemampuan pemecahan masalah matematis ditinjau dari perbedaan gender peserta didik. Hasil-hasil penelitian yang diuraikan di atas menunjukkan bahwa adanya keragaman hasil penelitian mengenai peran gender dalam proses pembelajaran matematika, namun pada sisi lain beberapa pendapat mengungkapkan bahwa gender tidak berpengaruh signifikan dalam pembelajaran matematika. Di karenakan $H_{0}$ ditolak, maka perlu dilakukan uji lanjut pasca anava untuk mengetahui secara signifikan tentang perbedaan rerata masing-masing kelompok penelitian.

Berikut rangkuman rerataan marginal pada Tabel 6., berikut:

Tabel 6. Rataan Marginal

\begin{tabular}{|l|l|l|l|}
\hline \multirow{2}{*}{$\begin{array}{l}\text { Model } \\
\text { Pembelajaran }\end{array}$} & \multicolumn{2}{|l|}{ Perbedaan Gender } & Rataan \\
\cline { 2 - 3 } & Perempuan & $\begin{array}{l}\text { Laki- } \\
\text { laki }\end{array}$ & Marginal \\
\hline Alqurun & 75,55 & 75,49 & 75,52 \\
\hline
\end{tabular}




\begin{tabular}{|l|l|l|l|}
\hline $\begin{array}{l}\text { Teaching Model } \\
\text { (ATM) }\end{array}$ & & & \\
\hline Konvensional & 72,32 & 65,86 & 69,09 \\
\hline Rataan Marginal & 73,935 & 0,675 & \\
\cline { 1 - 2 } & & \multicolumn{2}{|c|}{} \\
\cline { 1 - 2 } & &
\end{tabular}

$H_{0 A}$ ditolak, hal ini berarti terdapat perbedaan pengaruh model pembelajaran ATM terhadap kemampuan pemecahan masalah matematis tetapi karena model pembelajaran hanya memiliki dua kategori maka untuk antar baris tidak perlu dilakukan uji komperansi ganda dapat dipastikan bahwa hipotesis nolnya juga akan ditolak. Untuk mengetahui model pembelajaran manakah yang baik cukup dengan membandingkan besarnya marginal dari masing-masing model pembelajaran. Jika rataan marginal model pembelajaran ATM lebih besar daripada rataan marginal untuk pembelajaran konvensional berarti ATM dikatakan berpengaruh.

Rataan marginal model pembelajaran Alqurun Teaching Model (ATM) pada tabel 3. menunjukkan bahwa peserta didik yang mendapatkan perlakuan model ATM yaitu 75,52 lebih tinggi daripada rataan marginal yang mendapatkan perlakuan model pembelajaran konvensional yaitu 69,09.

Hasil uji perhitung komparasi ganda dapat dilihat pada tabel berikut ini:

Tabel 7. Hasil Uji Komparansi Ganda

\begin{tabular}{|l|l|l|l|l|}
\hline No & Interaksi & $\boldsymbol{F}_{\text {hitung }}$ & $\boldsymbol{F}_{\text {tabel }}$ & Kesimpulan \\
\hline 1 & $\mu_{1}$ vs $\mu_{2}$ & 7,164 & 4,013 & Ditolak \\
\hline 2 & $\mu_{1}$ vs $\mu_{3}$ & 1,841 & 4,013 & Diterima \\
\hline 3 & $\mu_{2}$ vs $\mu_{3}$ & 1,774 & 4,013 & Diterima \\
\hline
\end{tabular}

Berdasarkan Tabel 7. Pada hipotesis nol yang pertama, diperoleh kesimpulan bahwa terdapat perbedaan yang signifikasi antara model pembelajaran ATM dengan model pembelajaran konvensional terhadap kemampuan pemecahan masalah matematis peserta didik yaitu sebesar 7,164. Dari tabel 6., dapat disimpulkan bahwa kemampuan pemecahan masalah matematis peserta didikyang mendapatkan model pembelajaran
ATM lebih baik dibandingkan dengan model pembelajaran konvensional. Hasil ini sekaligus melengkapi penelitian-penelitian sebelumnya terkait penelitian menggunakan model pembelajaran Alqurun Teaching Model (Astri Setyawati, 2017) yang menghasilkan adanya peningkatan kemampuan komunikasi matematis peserta didik.

Selanjutnya pada hipotesis nol yang kedua di tabel 7., diperoleh tidak terdapat pebedaan antara model pembelajaran ATM dengan perbedaan gender terhadap kemampuan pemecahan masalah matematis peserta didik yaitu sebesar 1,841. Hasil penelitian ini senada dengan hasil penelitian Erna Pasanda yang menyatakan bahwa gender tidak berpengaruh terhadap pertimbangan auditor (Pasanda, 2013).

Pada hipotesis nol yang ketiga di tabel 7, diperoleh tidak terdapat perbedaan antara model pembelajaran konvensional dengan perbedaan gender terhadap kemampuan pemecahan masalah matematis peserta didik yaitu sebesar 1,774. Hasil ini juga sesuai penelitian S. Fedi yang menunjukkan bahwa tidak terdapat perbedaan tingkat apresiasi matematika antara peserta didik laki-laki dengan peserta didik perempuan (Siregar, 2010). Karna di dalam Alqur'an tidak ada sedikit pun pembeda baik antara laki-laki maupun perempuan (Pasanda, 2013).

Dari hasil kemampuan pemecahan masalah matematis peserta didik terhadap perbedaan signifikasi antara model pembelajaran Alqurun Teacbing Model dengan model pembelajaran konvensional. Peserta didik yang menerapkan model pembelajaran Alqurun Teaching Model menghasilkan kemampuan pemecahan masalah matematis lebih baik daripada peserta didik yang menerapkan model pembelajaran konvensional. 


\section{Kesimpulan}

Berdasarkan hasil analisis penelitian dan pengujian hipotesis maka diperoleh kesimpulan bahwa terdapat pengaruh antara model pembelajaran Alqurun Teaching Model terhadap kemampuan pemecahan masalah matematis peserta didik. Selain itu, tidak terdapat pengaruh perbedaan gender terhadap kemampuan pemecahan masalah matematis peserta didik. Selain itu, tidak terdapat interaksi antara model pembelajaran dan perbedaan gender terhadap kemampuan pemecahan masalah matematis peserta didik.

\section{Daftar Kepustakaan}

Agustiana, E., Putra, F. G., \& Study, L. (2018). Pengaruh Auditory, Intellectually, Repetition ( AIR) dengan Pendekatan Lesson Study terhadap Kemampuan Pemecahan Masalah Matematis. Desimal: Jurnal Matematika, 1(1), 1-6.

Amalia, R. (2017). Efektivitas Pembelajaran Alqurun Teaching Model (ATM) Ditinjau Dari Kemampuan Pemahaman Konsep Pangkat Tak Sebenarnya. Skripsi Universitas Lampung.

Amir MZ, Z. (2013). Perspektif Gender dalam Pembelajaran Matematika. Marwah, 12(1), 14-31.

Astri Setyawati. (2017). Pengembangan LKPD Berbasis Alqurun Teaching Model untuk Meningkatkan Kemampuan Komunikasi Matematis Peserta Didik. Skripsi Universitas Lampung.

Djamrah, S. B., \& Zain, A. (2010). Strategi Belajar Mengajar. Jakarta: Rineka Cipta.

Fedi, S., Sariyasa, \& Suparta, I. N. (2014). Tingkat Kecemasan dan Apresiasi Matematika Ditinjau dari Gender pada Siswa kelas VIII SMP Negeri Sekecamatan Poco Ranaka Barat, Kabupaten Manggarai Timur Tahun Ajaran 2013/2014. Jurnal Stkip Santu Paulus.
Hasnah, N. (2017). Bias Gender Dalam Buku Ajar Al-Arabiyah Linnaasyiin. Humanisma: Jurnal of Gender Studies, 1, 6174.

Herman Hudoyo. (1998). Mengajar Belajar Matematika. Jakarta: DEPDIKBUD.

Indah Muliati dan Muhamad Rezi, "Tujuan Pendidikan Dalam Lingkup Kajian Tafsir Tematik Pendidikan," Islam Transformatif: Journal of Islamic Studies 1, no. 2 (March 6, 2018):177-90, https://doi.org/10.30983/IT.V1I2.475.

Imamuddin, M., \& Isnaniah. (2017). Kemampuan Spasial Mahasiswa Laki-laki dan Perempuan Dalam Menyelesaikan Masalah Geometri. Humanisma: Jurnal of Gender Studies, 1, 38-47.

Novalia, \& Syazali, M. (2014). Olah Data Penelitian. Bandar Lampung: Aura.

Oktiana, T. (2017). Bahan Ajar Berbasis Alqurun Teacbing Model (ATM) Pada

Konsep Materi Lingkaran. Tesis Universitas Lampung.

Pasanda, E. (2013). Pengaruh Gender dan Pengalaman Audit. Jurnal Akuntansi Multiparadigma, 4(3)

Puspitasari, Y. (2017). Pengembangan LKPD Berbasis Alqurun Teaching Model untuk meningkatkan Pemahaman Konsep Matematika. Skripsi Universitas Lampung.

Rahma, S., Farida, \& Suherman. (2017). Analisis Berpikir Kritis Siswa dengan Pembelajaran Socrates Kontekstual di SMP Negeri 1 Padangratu Lampung Tengah. Prossiding Seminar Nasional Pendidikan IPA FITKUIN Syarif Hidayatullah Jakarta.

Rosalina, T. (2008). Pengaruh Manajemen Pembelajaran Full Day School Terhadap Motivasi Belajar. Manajemen Pendidikan, 23(5), 434-438.

Ruseffendi, E. T. (1991). Penilaian Pendidikan dan Hasil Belajar Siswa khususnya dalam Pengajaran Matematika. 
Sanjaya, W. (2006). Strategi Pembelajaran

Berorientasi Standar Proses Pendidikan.

Bandung: Kencana Media.

Siregar. (2010). Teori Belajar dan Pembelajaran. Jakarta: Ghalia Indonesia.

Soemarno U dan Hendriana H. (2014). Penilaian Pembelajaran Matematika. Bandung: PT Refika Aditama.

Subarinah, S. (2013). Profil Berpikir Kreatif Siswa dalam Memecahkan Masalah Tipe Investigasi Matematik Ditinjau dari Perbedaan Gender FMIPA UNY. Seminar Nasional Matematika dan Pendidikan Matematika.

Suherman, E. (2003). Strategi Pembelajaran Matematika Kontemporer. Pascasarjana IKIP Bandung: Tidak diterbitkan.

Syawaluddin. (2017). Konsep Diri Anak Ditinjau Dari Jenis Kelamin Di Panti Asuhan Kota Padang. Humanisma: Jurnal of Gender Studies, 1(1), 75-86.

Wulandari, P., Mujib, \& Ganda Putra, F. (2016). Pengaruh Model Pembelajaran Investigasi Kelompok berbantu Perangkat Lunak Maple terhadap Kemampuan Pemecahan Masalah Matematis. Al-Jabar: Jurnal Pendidikan Matematika, 7(1), 101-107.

Yamin, M. (2007). Profesionalisasi Guru dan Implementasi KTSP. Jakarta: Gaung Persada Press.

Yenda Bella Putri. (2017). Pengembangan Bahan Ajar Berbasis Alqurun Teaching Model Pada Teorema Phytagoras. Skripsi Universitas Lampung. 